University of Wollongong

Research Online

$1-1-2019$

Do Accruals Earnings Management Constraints and Intellectual Capital Efficiency Trigger Asymmetric Cost Behaviour? Evidence from Australia

Yiru Yang

University of Wollongong, yy449@uowmail.edu.au

Follow this and additional works at: https://ro.uow.edu.au/buspapers

Part of the Business Commons

Research Online is the open access institutional repository for the University of Wollongong. For further information contact the UOW Library: research-pubs@uow.edu.au 


\title{
Do Accruals Earnings Management Constraints and Intellectual Capital Efficiency Trigger Asymmetric Cost Behaviour? Evidence from Australia
}

\author{
Abstract \\ This study examines whether accruals earnings management constraints and intellectual capital (IC) \\ efficiency affect asymmetric cost behaviour by analysing data for the 1990 to 2016 period on firms listed \\ on the Australian Securities Exchange. The analysis reveals that, on average, anti-sticky cost behaviour \\ occurs when firms have limited ability to engage in accrual earnings management to manipulate earnings \\ in the current year. Further, IC efficiency - particularly human capital efficiency - increases the degree of \\ cost stickiness. This study also finds that the degree of asymmetric cost behaviour is more pronounced \\ in the post-International Financial Reporting Standards (IFRS) period than in the pre-IFRS period. The \\ results suggest that the increased asymmetric cost behaviour in the post-IFRS period derives from higher \\ IC efficiency relative to the pre-IFRS period. This study presents important implications for external \\ stakeholders because they can consider the extent of earnings management constraints and the extent \\ of firms' IC efficiency as the determinants of asymmetric cost behaviour when assessing firms' cost \\ behaviour. \\ Disciplines \\ Business

\section{Publication Details} \\ Yang, Y. (2019). Do Accruals Earnings Management Constraints and Intellectual Capital Efficiency Trigger \\ Asymmetric Cost Behaviour? Evidence from Australia. Australian Accounting Review, 29 (1), 177-192.
}


Do Accruals-earnings Management Constraints and Intellectual Capital Efficiency

Trigger Asymmetric Cost Behaviour? Evidence from Australia

\author{
Yiru Yang \\ University of Wollongong
}

JEL classification M41

Corresponding author: Yiru Yang, Address: Northfields Ave, Wollongong NSW 2522. Tel.+61 423721342. Email: yy449@uowmail.edu.au 
Do Accruals-earnings Management Constraints and Intellectual Capital Efficiency Trigger Asymmetric Cost Behaviour? Evidence from Australia

\section{Summary at a glance}

This study examined whether accruals earnings management constraints and intellectual capital (IC) efficiency affect asymmetric cost behaviour. It found that, on average, when firms experience accruals earnings management constraints in avoiding unfavourable earnings in the current year, they tend to cut slack resources aggressively, leading to increased anti-sticky cost behaviour. Further, IC efficiency increases the degree of cost stickiness owing to managers' optimistic expectations about sales. Lastly, asymmetric cost behaviour has intensified in the post-International Financial Reporting Standards (IFRS) period owing to increased IC efficiency after IFRS adoption. 


\begin{abstract}
This study examines whether accruals-earnings management constraints and intellectual capital (IC) efficiency affect the asymmetric cost behaviour of managers by analysing data for the 1990 to 2016 period on firms listed on the Australian Securities Exchange. The analysis results reveal that, on average, anti-sticky cost behaviour occurs when firms have limited ability to engage in accrual-earnings management to manipulate earnings in the current year. Further, IC efficiency-particularly human capital efficiency - increases the degree of cost stickiness. This study also finds that the degree of asymmetric cost behaviour is more pronounced in the post-International Financial Reporting Standards (IFRS) period than in the pre-IFRS period. The results suggest that the increased asymmetric cost behaviour in the post-IFRS period derives from higher IC efficiency relative to the pre-IFRS period. This study presents important implications for external stakeholders because they can consider the extent of earnings management constraints and the extent of firms' IC efficiency as the determinants of asymmetric-cost behaviour when assessing firms' cost behaviour.
\end{abstract}

Keywords: asymmetric-cost behaviour, accruals-earnings management constraints, intellectual capital efficiency, earnings targets, International Financial Reporting Standards. 


\section{Introduction}

Over the past decade, the assumption that cost behaviour is asymmetric rather than symmetric for activity volume increases and decreases has emerged in management accounting literature. Asymmetric cost behaviour was first investigated by Anderson et al. (2003), drawing considerable academic attention. Asymmetric cost behaviour arises when the cost response to a decrease in activity is smaller or greater than the cost response to an increase in activity. Such cost behaviour can be further defined as sticky or anti-sticky (Weiss 2010) — costs are termed sticky when the costs rise more with increases in activity volume than they fall with decreases of the same amount (Anderson et al. 2003), and they are termed anti-sticky when the costs fall more with deceases in activity volume than they rise with increases of the same amount (Weiss 2010). According to Weiss (2010), a firm with stickier costs shows a greater decline in earnings when the activity level falls than a firm with less sticky costs does, as stickier costs result in a smaller cost adjustment when activity level declines and, therefore, lower cost savings. Lower cost savings result in a greater decrease in earnings, on the other hand, a firm with anti-sticky costs shows a smaller decline in earnings when the activity volume falls than a firm with sticky costs does, as anti-sticky costs result in a greater cost adjustment when activity volume declines and, therefore, a lower decrease in earnings. Asymmetric cost behaviour has been explained in several ways, but the most common explanation is associated with cost-benefit management capacity decisions in the face of changing demand (Cannon 2011).

Several studies have investigated asymmetric-cost behaviour finding that asymmetric-cost behaviour is seen in firms in the United States (US) (e.g. Anderson et al. 2003; Balakrishnan et al. 2004; Bosch and Blandon 2011; Chen et al. 2012); Japan (e.g. He et al. 2010), Australia (e.g. Bugeja et al. 2015), as well as in other countries (e.g. Porporato and Werbin 2010; Calleja et al. 2006). However, asymmetric-cost behaviour is still in its infant stage and it is worth to expand (Banker et al., 2017). Bugeja et al. (2015) stated that there is little empirical evidence on how costs behave in Australia. 
Banker et al. (2017) categorised the determinants of cost behaviour into constraints (e.g., the existence of adjustment costs, changes in economic activity amount, and debt covenants), managers' incentives (e.g., meeting earnings targets, avoiding earnings declines or losses, and ownership types) and expectation biases (e.g., managers' optimistic or pessimistic expectations regarding sales). They stated that the extant accounting literature does not comprehensively clarify whether cost stickiness is 'good' cost stickiness (e.g., it primarily reflects rational or strategic resource management that drives future sales to avoid adjustment costs) or 'bad' (e.g., it reflects wasteful overspending owing to an agency problem). Moreover, Banker et al. (2017) proposed extending empirical cost stickiness tests should incorporate the dynamic role of resource investment as a driver of future revenue.

This study attempts to fill this gap in the literature. First, this study stems from the agency theory, which suggests that managerial incentives to gain personal wealth (Chen et al. 2012) and/or concerns about meeting or beating earnings benchmarks drive the degree of cost stickiness (Kama and Weiss 2013). This study attempts to examine whether accruals-earnings management constraints of firms could trigger the asymmetric cost behaviour of their management. The rationale behind this investigation is that when firms have limited ability to manipulate their earnings to avoid unfavourable results, managers could adjust cost by increased cutting down of slack resources during a period of declining sales to deliberately increase earnings. Second, this study stems from managerial expectations related to sales decline. Studies have revealed that factors such as overconfidence influence managers' resource commitment decisions (Chen et al. 2015; Qin et al. 2015) and hubris (Yang 2015). Optimistic (pessimistic) expectations in relation to sales declines lead to an increase (decrease) in cost stickiness (Anderson et al. 2003). Researchers believe that intellectual capital (IC) can yield economic benefits and enhance firm performance (e.g., Joshi et al., 2013; Clarke et al., 2011). When IC is efficient, managers could be optimistic regarding future earnings and would retain current unutilised resources even in case of decline in sales. They might believe that the increase in future sales generated using IC would absorb the cost of unutilised resources, and hence, this belief would lead to cost stickiness. Therefore, this study examines whether IC efficiency induces asymmetric cost behaviour. 
This study chose Australia for the following reasons: first, as Bugeja et al. (2015) stated, most studies on cost stickiness focus on the United States (US), but significant variations exist between Australia and the US as regards market competition, firm characteristics, economic structure, governance environment and major industries.

Second, Australia, as a country with a balance sheet-oriented conceptual framework, common law legal system, high level of shareholder protection and low conformity between taxation reporting and financial accounting, differs from the US in terms of regulatory and reporting environments (Chalmers et al. 2008, 2011; Lont et al. 2010). Unlike in the US, the regulatory environment in Australia allows a more 'principlesbased' other than 'rules-based' approach in many areas, including compliance with accounting standards (Lont et al. 2010). In addition, the latter's reporting environment differs from that of the former in terms of the extent of analyst following and institutional setting (Coulton et al. 2005). Analyst following of Australian companies is considerably less intensive compared with that of US companies (Habib and Hossain 2008).

Further, Australian institutional investors are less likely than their US counterparts to seek to use their voting power to influence management behaviour (Craswell et al. 1997; Wilson and Wang 2010). Unlike in the US, where earnings manipulation is the dominance of equity-based compensation schemes, in Australia, although executive stock options are awarded, it has not been a widespread practice (Coulton et al. 2005). Around one-third of the CEOs in Australia's largest firms did not receive any equitybased compensation (Matolcsy and Wright 2007). These differences could lead to variations between the two countries in cost behaviour arising from managerial operating decisions.

Lastly, Australia provides an ideal ground for IC reporting because it has experienced fast economic growth and is also undergoing a transformation with an increasing emphasis on new sectors, such as niche manufacturing, information technology, tourism and financial services. It is also experiencing a relative decline in its traditionally strong areas of mining and agriculture (Guthrie et al. 1999; Abeysekera 2008). Australian firms were considered to follow 'best practices' in IC reporting (Guthrie et al. 1999; Guthrie and Petty 2000a, b). Guthrie et al. (2006) found that Australian companies in 
2002 disclosed more IC information than Australian companies in 1998 and Hong Kong companies in 2002. In a comparison of Australia and Sri Lanka, Abeysekera (2007) demonstrated that Australian firms were far more involved in research and development, investors in Australia were more willing to support entrepreneurship and Australia has more comprehensive laws to protect intellectual property rights. Therefore, Australia provides a good context to study IC and its influence on managers' operating decision-making.

The purpose of this study is to examine whether accruals-earnings management constraints and IC efficiency affect management asymmetric cost behaviour of firms listed on the Australian Securities Exchange (ASX). The results reveal the existence of anti-sticky cost behaviour when firms have limited ability to apply accruals earnings management to manipulate their earnings. The effect intensifies when firms have incentives to avoid unfavourable earnings (i.e., earnings declines or losses). When managers have strong incentives to avoid earnings decrease or losses but have limited ability to engage in accruals-earnings management, they are more willing to cut costs aggressively during periods of weak demand. Further, the study finds that IC efficiency_particularly human capital efficiency_increases sticky cost behaviour. The results demonstrate that under IC efficiency, managers believe that IC will generate future revenue. Even there is a decline in sales in current year, but the managers may believe decline is temporary and therefore they decide to carry the cost of unutilised resources, because they believe the cost absorption will occur during periods of increasing demand in the future. In the additional test, this study examines whether the adoption of International Financial Reporting Standards (IFRS) could influence asymmetric cost behaviour. This study finds that such behaviour is more pronounced in the post-IFRS period as the results of higher IC efficiency in the post-IFRS period compared with the pre-IFRS period.

This paper contributes to the literature on asymmetric-cost behaviour in three significant ways. First, although there is a rapid growth in studies on asymmetric-cost behaviour, most studies focus on investigating cost stickiness, and few seek to examine both sticky and anti-sticky-cost behaviour. This study extends prior research to investigate total asymmetric-cost behaviour and its two components (i.e., sticky and 
anti-sticky-cost behaviour) in Australian ASX-listed firms. Second, prior research provides evidence that corporate governance (Chen et al. 2012), firm size (Via and Perego 2014; Anderson et al. 2003), industry (Subramaniam and Weidenmier 2003; Via and Perego 2014), labour market (Banker and Chen 2006; Banker et al. 2013), employee intensity (Anderson et al. 2003) affect sticky-cost behaviour. This study examines whether IC efficiency affects asymmetric-cost behaviour and whether increasing IC efficiency influences asymmetric-cost behaviour. Third, agency problem has been cited as a cause of asymmetric-cost behaviour (because managers are motivated to deliberately manage costs) (e.g. Chen et al. 2012; Kama and Weiss, 2013); however, to the best of the researcher's knowledge, there is no empirical study that examines how managers deliberately manage costs when firms have limited ability to manage earnings using accruals. Thus, this study adds to the literature on asymmetriccost behaviour by examining whether asymmetric costs are exhibited when firms have limited ability to apply accruals-earnings management.

The remainder of the paper is presented as follows. Section 2 provides a literature review. Section 3 provides hypotheses development of this study. Section 4 describes the research design including sample selection and the empirical models. Section 5 provides the descriptive statistics, correlation of the variables and regression results. Section 6 provides the additional tests. Section 7 presents conclusion.

\section{Literature Review}

Analysing cost behaviour is a critical topic in the management accounting research. Anderson et al. (2003) provided the first empirical evidence that costs behave asymmetrically in relation to a firm's activity volume. The study examined asymmetric behaviour in selling, general and administrative (SG\&A) costs using a sample of 7629 US firms over a period of 20 years. The study found that SG\&A costs increased 0.55 percent per one percent increase in sales, but decreased only 0.35 percent per one percent decrease in sales, on average. The authors labelled this behaviour 'sticky'. Several studies have confirmed Anderson et al.'s (2003) results, finding that US firms exhibit significant cost stickiness (e.g. Balakrishnan et al. 2004; Bosch and Blandon 2011; Chen et al. 2012). 
Cost stickiness has also been investigated in an international context. He et al. (2010) observed whether SG\&A costs are sticky in Japanese firms using a sample of 1802 firms over 25 years. Their results suggested that sticky cost behaviour is present in Japanese firms. They found evidence that SG\&A costs increased 0.59 percent every one percent increase in sales, but fell only 0.45 percent every one percent decrease in sales, on average. Özkaya and Yükcü (2011) provided evidence of stickiness in both SG\&A costs and total operating costs in non-financial Turkish firms, while Porporato and Werbin (2010) found the existence of sticky costs in the banking sectors of Argentina, Brazil and Canada. Calleja et al. (2006) investigated whether stickiness in operating costs is exhibited in four countries: UK, US, German and French firms. The results showed that cost stickiness was exhibited in all four countries, but found that the stickiness was weaker in US and UK firms relative to French and German firms. Banker and Chen (2006) examined whether Organisation for Economic Co-operation and Development (OECD) countries present different cost behaviour. The authors examined the sticky behaviour of operating costs using a sample of 12666 firms from 19 OECD countries over 10 years. The study provided evidence that the degree of cost stickiness differs across these 19 countries significantly, and that features of the labour market are important determinants of this cross-country difference.

A debate on cost stickiness has emerged recently in the literature, regarding the possibility that the degree of cost stickiness might vary systematically across different cost structures, firm's characteristics, and the possibility of no stickiness or stickiness (e.g. Anderson and Lanen 2009; Weiss 2010; Balakrishnan et al. 2014). Anderson and Lanen (2009) explored sticky cost behaviour related to SG\&A costs and other types of costs, including advertising, labour wages, headcount, research and development, and property, plant and equipment. They presented evidence that cost changes are almost equally likely to exhibit asymmetries of both the sticky and anti-sticky variety, as they are to vary linearly with sales revenue changes. Via and Perego (2014) examined asymmetric cost behaviour in small- and medium-sized Italian firms over the period 1999-2008 and found that operating costs in the trading industry exhibited sticky behaviour. 
Many studies currently investigate factors that drive asymmetrical cost behaviour. To reiterate, the literature mentions three types of drivers of cost stickiness (i.e., constraints, managers' incentives and biases). First, managers choose resource levels subject to various constraints (e.g., the existence of adjustment costs, changes in economic activity amount, debt covenants). When the constraints (e.g., adjustment costs) are larger, managers are more willing to retain unused resources during periods of sales decrease. Researchers confirm that constraints play a role in cost management decisions. For example, Anderson et al. (2003) used asset intensity and employee intensity as proxies for firm-level constraints, and Banker et al. (2013b) used the strictness of employment protection laws in OECD countries as a country-level constraint proxy. They both found that these management constraints could trigger asymmetric cost behaviour. A high level of constraints hinders managerial decisionmaking on reducing optional resources in proportion to decreased economic activity (Balakrishnan et al. 2014; Banker et al., 2017).

Secondly, the degree of cost stickiness is affected by mangers' incentives (e.g., meeting earnings targets, avoiding earnings declines or losses). Chen et al. (2012) examined the influence of the agency problem and corporate governance on the degree of cost stickiness using the data of US firms over 10 years. The authors found a positive relationship between the agency problem and the degree of cost asymmetry. The positive relationship between the agency problem and the degree of cost asymmetry is mitigated by strong corporate governance, suggesting that strong corporate governance can help to mitigate the effect of the agency problem on the degree of cost asymmetry. Kama and Weiss (2013) examined whether managers' incentives of avoiding losses or meeting earnings targets influence the degree of costs stickiness. Their results showed that when managers face incentives to avoid earnings decreases or losses, or to meet financial analysts' earnings forecasts, the degree of cost stickiness is reduced, indicating that incentives of avoiding losses or meeting earnings targets induce managers expedite downward adjustment of unused resources for sales decreases. Bugeja et al. (2015) examine the characteristics and determinants of cost stickiness in Australia using a sample of Australian listed firms from the period 1990-2010, and found that on average, Australian firms exhibit sticky-cost behaviour. They also found that the degree of cost stickiness increased after the adoption of IFRS, and that an increase in 
managers' incentives to avoid decreases in earnings or losses reduces sticky-cost behaviour.

Third, managers' expectation biases regarding projected sales levels (e.g., their optimistic or pessimistic expectations in relation to sales declines) can affect their cost behaviour. Banker et al. (2016a) provided evidence that cost stickiness, along with conservatism, determines asymmetric timeliness of earnings. Anderson et al. (2003) revealed that managerial optimism increases cost stickiness. Banker et al. (2014) proxied for expectations using different combinations of sales increase and decrease over two consecutive periods. As expected, they found significant cost stickiness in the optimistic scenario (two successive periods of sales increase) and significant cost antistickiness in the pessimistic scenario (two successive periods of sales decrease). Banker et al. (2016b) use capacity utilisation as a proxy for optimism and found that high capacity utilisation is associated with greater cost stickiness. Thus, the empirical evidence consistently shows that concurrent demand changes as well as managers' forward-looking demand expectations influence cost management decisions in the current period.

\section{Hypotheses development}

As an extension of the argument that managers' incentives drive the degree of cost stickiness (Bugeja et al. 2005; Kama and Weiss 2013; Banker et al. 2017), this study aims to understand whether cost stickiness occurs when firms have limited ability to use accruals earnings management to manage earnings in the current year.

Apart from cost management, managers have several techniques they can employ to avoid earnings decreases, and managers must balance the cost benefit of employing different techniques (Palmrose et al. 2004; Desai et al. 2006). Accruals-earnings management is a popular choice because it has no first-order effect on cash flows (Badertscher 2011; Doukakis 2014; Gunny 2010). However, accruals-earnings management has limitations. First, aggressive choices about accruals are at a higher risk of regulatory litigation and scrutiny because accrual accounting choices are subject to auditor scrutiny, and high levels of accrual manipulation tend to be discovered by regulators (Graham et al. 2005), particularly for public listed firms. Second, the reverse 
nature of accruals-earnings management can be problematic because a firm must conquer the potential reversal of the previous year's accruals-earnings management to influence the current year's earnings (Badertscher 2011). This paper aims to examine whether accruals constraints affect managers' incentives to employ cost management to avoid earnings declines by deliberately cutting slack resource. Cutting slack resources aggressively when there is decline in sales could help managers avoid earnings declines or losses when managers have limited ability to utilise the accruals earnings management to avoid unfavourable earnings in the current year results. This could result in the firm exhibiting asymmetric-cost behaviour in the current year. Given that this study is the first to examine accruals-earnings management constraints as a determinant of cost asymmetry, the paper states the hypothesis in a null form as follows:

\section{H1: Accruals-earnings management constraints do not influence the degree of cost asymmetry.}

IC was recognised as being significant and therefore it became desirable to measure and report IC as a means of creating and managing a firm's sustainable competitive advantage (Guthrie et al. 2012). In recent decades, the term 'IC' has been used as an instrument of value creation, which has led to interdisciplinary researchers investigating how the capital market has reacted to the potential of IC to create firm value (Dumay and Tull, 2007; Murthy and Abeysekera, 2007; Guthrie et al., 2012). Guthrie and Petty (2000c) suggest that IC is used as a foundation on which to create and use knowledge to enhance firm value, which means that IC refers to the ability to translate organisational knowledge into value. IC underlines the importance of using the capital generated by resources and human beings to generate products and services in a competitive manner, and this is reflected in strong firm performance and the creation of value (Phusavat et al. 2011; Guthrie et al. 2012; De Silva et al. 2014).

Evidence about IC and firms' financial performance in Australia generally supports the belief that IC can enhance their financial performance as well as convey useful forward-looking financial information that is relevant to investors evaluating firm value. For example, Joshi et al. (2013) examined the relationship between IC, measured by Pulic (1998)'s value-added intellectual coefficient $(\mathrm{VAIC})^{\mathrm{TM}}$, and firm financial performance, measured by return on assets (ROA), in the Australian financial sector for 
the 2006-2008 period. They found that in all Australian-owned banks, human capital is slightly more efficient than structural capital and capital employed. Clarke et al. (2011) examined the effect that IC efficiency has on the performance of Australian listed firms between 2004 and 2008. They measured IC efficiency using VAIC ${ }^{\mathrm{TM}}$ and financial performance by return on equity, ROA, revenue growth and employee productivity. The results indicated a positive relationship between IC efficiency and firm performance, particularly in the case of capital employed efficiency (CCE) and human capital efficiency (HCE), as well as between HCE and structural capital efficiency (SCE) in the prior year and performance in the current year. Kim and Taylor (2014) compared the value relevance of the productivity of IC and its components, and the productivity of the book value of assets using data from 2006 to 2010 on a sample of 160 Australian listed firms. They developed models that drew on publicly available share prices and financial information to compute and compare the value relevance of the productivity of IC as well as its components of structural and human capital. They measured IC using a components-based direct IC measurement on hand-collected annual reports. The results showed that the productivity of structural capital, human capital and IC were each positively associated with share price, whereas the productivity of total assets at book value was insignificant and of tangible assets was negatively significant. The authors concluded that the book value of intangible and tangible assets in the balance sheet has no value relevance, while intangible assets in the balance sheet represent only a fraction of IC.

This study assumes that efficient use of IC will enhance firms' financial performance. If firms experience a decrease in sales, managers may prefer to sustain current unutilised resources because they feel confident in the increased future firm performance that may be generated by IC. This is based on the argument that, when managers are optimistic about future performance, they are willing to retain unused resources during periods of sales decrease because they believe cost absorption will occur during periods of increased firm performance in the future. This tendency to retain resources should increase cost stickiness (Anderson et al. 2003; Banker et al. 2017). This study assumes that IC efficiency could trigger sticky cost behaviour because IC could bring future economic benefits to firms. Managers could believe the future economic benefits will absorb the costs incurred during periods of sales decrease. 
However, to the best of the researcher's knowledge, no study has examined empirically whether IC efficiency and its three components-HCE, SCE and CEE - lead to asymmetric cost behaviour in Australia. This paper thus states hypothesis in a null form below:

H2: IC efficiency and its three components (i.e., HCE, SCE and CEE) do not influence the degree of cost asymmetry.

\section{Research Design}

Data and Sample Selection

This study used ASX-listed firms from years 1990-2016. The data were obtained from the Morningstar DatAnalysis supplementary by Compustat Global Vantage database ${ }^{2}$. The sample period starts from 1990 because there is no data in the Morningstar DatAnalysis database prior 1990. Firms involved in the financial and real estate sectors were excluded because they are subject to different reporting requirements. Following prior literature (e.g. Anderson et al. 2003; Via and Perego 2014), this study excluded the firm-year observations with negative book value of equity, negative total assets, or negative or missing sales revenue. This study also trimmed the top and the bottom $1 \%$ of the sample and excluded sample firms with missing data for the interested and control variables (see Empirical model to test the hypotheses). The final sample consisted of 10048 firm-year observations.

Measurement of Accruals Earnings Management Constrains

Due to the constrained flexibility of accruals, the ability of managers to manage accruals upwards in the current period is limited by accrual management activities in previous periods. This paper follows previous studies (Badertscher 2011; Barton and Simko, 2002; Zang, 2012), where net operating assets are used as a proxy for the extent

\footnotetext{
2 Data about employee salaries and wages are not available in DatAnalysis, and this study hence obtained such data from the Compustat Global Vantage database.
} 
of accruals management in previous periods to represent a firm's ability to manage earnings using accruals. If the net operating assets at the beginning of the year are high, managers' abilities to use accruals to manipulate earnings are reduced in the current year because the balance sheet and income statement are articulated. Therefore, abnormal accruals shown in past earnings can also be shown in net assets, and hence the latter are overstated when firms have practiced accruals management previously (Barton and Simko, 2002; Zang, 2012). Net operating assets at the beginning of a year (NOA) is measured by shareholders' equity minus cash and cash equivalent, plus total debt divided by lagged sales for firm $j$, at the beginning of year $t$. Therefore, NOA consists mainly of accrual-based measures of net assets used in operations. This proxy is consistent with the assumption that overstated net assets are less efficient at generating a given level of sales, all else equal (Barton and Simko, 2002).

\section{Measurement of IC Efficiency}

Following Chen et al. (2005) and Clarke et al. (2011), IC efficiency is calculated using Pulic (1998)'s VAIC (i.e., value added intellectual coefficient). VAIC includes three components: human capital efficiency, structural capital efficiency, and capital employed efficiency.

To calculate VAIC, the first step is to calculate the ability of a firm to create value added (VA) to all stakeholders. Following previous studies (e.g. Chen et al. 2005; Tan, Plowman, and Hancock 2008; Clarke et al. 2011), VA can be expressed as follows:

$\mathrm{VA}=\mathrm{S}-\mathrm{B}=\mathrm{NI}+\mathrm{W}+\mathrm{T}+\mathrm{I}+\mathrm{DP}$

where: $\mathrm{S}$ is net sales revenues (output); B is cost of goods sold (input); NI is net income after tax; W is employee wages and salaries; $\mathrm{T}$ is taxes; I is interest expense; and DP is depreciation.

\section{Human capital efficiency (HCE)}

Human capital (HC) includes the knowledge, experiences, skills, productivity, and employees competence (Clarke et al. 2011). HCE is calculated as:

$\mathrm{HCE}=\mathrm{VA} / \mathrm{HC}$ 
$\mathrm{HC}$ is defined as salaries and wages at a point in time (Pulic, 1998). HCE indicates the amount of VA generated by a dollar spent on HC.

Structural capital efficiency (SCE)

Structural capital (SC) includes IC items such as strategy, organisational networks, patents, and brand names. Pulic (1998) calculates SCE as follows:

$\mathrm{SCE}=\mathrm{SC} / \mathrm{VA}$

SC is measured as VA minus HC. SCE, therefore, demonstrates the dollar of SC within the firm, for every dollar of value that is added, and as HCE increases, SCE increases.

Capital employed efficiency (CEE)

Capital employed efficiency (CEE) includes the efficiency that HCE and SCE fail to capture. Pulic (1998) argues that IC cannot create value on its own, and so must be combined with (physical and financial) capital employed (CE).

CEE is defined as:

$\mathrm{CEE}=\mathrm{VA} / \mathrm{CE}$

$\mathrm{CE}$ is calculated as total assets minus intangible assets and CEE demonstrates the amount of VA created by a dollar spent on CE.

VAIC

VAIC includes the three individual efficiencies and is the aggregation of the three efficiencies:

$\mathrm{VAIC}=\mathrm{HCE}+\mathrm{CEE}+\mathrm{SCE}$

A greater VAIC represents greater efficiency in IC capitals employed, and thus greater value generated to the firm. 
Empirical Model to test the hypotheses

Many empirical studies have measured cost behaviour using the asymmetrical cost regression model of Anderson et al. (2003) (e.g. Balakrishnan et al. 2004; Chen et al. 2012; Via and Perego, 2014; Bugeja et al., 2015). This study also relies on the Anderson et al. (2003)'s model and extends the model by including two additional determinants (i.e., NOA and VAIC), which is presented as below:

$$
\begin{aligned}
& \log \left(\frac{\operatorname{cost}_{\mathrm{j}, \mathrm{t}}}{\operatorname{Cost}_{\mathrm{j},-1}}\right)=\beta 0+\beta 1 \log \left(\frac{\operatorname{Sales}_{\mathrm{j}, \mathrm{t}}}{\operatorname{Sales}_{\mathrm{j}, \mathrm{-}-1}}\right)+\beta 2 D_{\mathrm{j}, \mathrm{t}} * \log \left(\frac{\operatorname{Sales}_{\mathrm{j}, \mathrm{t}}}{\operatorname{Sales}_{\mathrm{j},-1}}\right)+\sum_{k=1}^{n} R_{\mathrm{k}} * \operatorname{DM}_{\mathrm{j}, \mathrm{t}, \mathrm{k}} * \\
& D_{\mathrm{j}, \mathrm{t}, \mathrm{k}} * \log \left(\frac{\operatorname{Sales}_{\mathrm{j}, \mathrm{t}}}{\operatorname{Sales}_{\mathrm{j}, \mathrm{t}-1}}\right)+\varepsilon j, t
\end{aligned}
$$

where: Cost is operating expenses and Sales is operating revenue. Decrease Dummy (D) is coded as 1 when operating revenues in year $t$ are less than those in year $t-1$, and zero otherwise. Coefficient $\beta 1$ measures the percentage increase in operating costs with a one percent increase in operating revenue. Because the value of $D$ is 1 when revenue decreases, the sum of the coefficients $(\beta 1+\beta 2)$ measures the percentage change in operating costs with a one percent decrease in operating revenue. A positive coefficient $\beta 2$ represents costs anti-stickiness, while a negative coefficient $\beta 2$ represents costs stickiness. $D M_{\mathrm{j}, \mathrm{t}, \mathrm{k}}$ is a determinant of cost stickiness, including NOA and VAIC. Following Bugeja et al. (2015) and Kama and Weiss (2013), this study included some other known determinants in the empirical model. They are gross domestic product $(G D P)$ growth rate; revenue decline in the preceding period (SUCC), which is a dummy variable coded ' 1 ' if revenue in $t-1$ is lower than revenue in $t-2$, and ' 0 ' otherwise; property, plant, and equipment intensity $(P P E)$, which is measured by the ratio of property, plant and equipment to sales; asset intensity (Asset), the ratio of total assets to sales; employee intensity $(E M P)$, the ratio of the employees' salaries to sales; managerial incentives to avoid unfavourable earnings (Avoid), which is a dummy variable coded ' 1 ' if Avoidloss $=1$ or Avoiddec $=1$, and ' 0 ' otherwise. Avoidloss is a dummy variable coded ' 1 ' if firm $j$ has earnings per share higher than or equal to zero but lower than one cent, and ' 0 ' otherwise. Avoiddec is a dummy variable coded ' 1 ' if earnings per share of firm $j$ is higher than or equal to that for the previous period but the difference is less than one cent, and ' 0 ' otherwise. Equations (6) includes time and industry effects to control for the unobservable confounding variables that differ across 
time but are constant across the industries, as well as those that differ across industries but are constant over time.

\section{Empirical Results}

\section{Descriptive Statistics}

Table 1 presents the summary statistics of variables for $\mathrm{H} 1$ and $\mathrm{H} 2$. The mean and median of NOA is 1.296 and 0.787 , respectively, indicating that the accruals-earnings management constraints exist in Australian firms and that these constraints are quite high. Further, the mean of VAIC is 0.868 and the median is 1.880 . Among the three IC components, $H C E$ has the highest mean $($ mean $=0.930)$, indicating that human capital accounts for the major part of IC in Australia. Similar to Bugeja et al. (2015), this study finds that the mean and median of $\Delta \log (\operatorname{Cost})$ is 0.105 and 0.077 , respectively. $\Delta \log ($ Sales $)$ has mean of 0.109 and median of 0.074 . The mean of Avoid is 0.308 , suggesting that managers have strong incentives to avoid unfavourable earnings (i.e., earnings declines or losses). On average, property, plant and equipment account for $67.8 \%$ of sales and employee salaries for $15.9 \%$.

$<$ Insert Table 1 about here $>$

Regression Results

Regression results for $\mathrm{H} 1$

Table 2 presents the year-industry fixed-effects ordinary least squares (OLS) regression results for H1. The results reveal that on average, cost stickiness is present in Australia, and as shown by the results for the first model in Table 2 , the estimated value of $\beta 1$ is $0.460(p$-value $=0.000)$, indicating that operating costs increase $0.460 \%$ per $1 \%$ increase in sales revenues. However, the estimated value of $\beta_{2}$ is -0.081 ( $p$ value $=0.002$ ), suggesting that costs decrease by $0.379 \%$ for a $1 \%$ decrease in sales revenues. The results remain the same on including control variables. The results presented for the second model show that the degree of cost stickiness increases with a firm's asset intensity (Asset), PPE intensity (PPE), and employee intensity (EMP), and 
the decreases when revenues reduce in the preceding period (SUCC), offering managers the incentive to avoid unfavourable earnings (Avoid). These results are generally consistent with those of Bugeja et al. (2015).

The third model shown in Table 2 demonstrates that $\triangle \log \left(\right.$ Sales ${ }^{*} D^{*} N O A$ is significant and positively associated with $\Delta \log (\operatorname{Cos} t)$ (coefficient $=0.011 ; p$ value $=0.005$ ), indicating that when firms have limited ability to use accruals to manage earnings, managers tend to cut unutilised costs when sales decline and to constrain resource expansion when sales increase. This approach results in costs becoming antisticky. This result is also confirmed by including the control variables shown in fourth model. Moreover, the results in Table 2 reveal that managers' incentive to avoid unfavourable earnings intensifies the relationship between $N O A$ and the degree of antisticky cost behaviour. The fifth model shows that $\Delta \log ($ Sales $) * D^{*} N O A * A v o i d$ is significant and positively associated with $\Delta \log (\operatorname{Cos} t)$ (coefficient $=0.032 ; p$ value $=0.003$ ), indicating that when managers have incentives to avoid unfavourable earnings but have limited ability to apply accruals-earnings management to manage earnings, they are more willing to cut slack resources aggressively to meet current earnings targets.

$<$ Insert Table 2 about here $>$

\section{Regression Results for $\mathrm{H} 2$}

Table 3 presents the year-industry fixed-effects OLS regression results for H2. The results for the first model in Table 3 indicate that on average, total IC efficiency increases the degree of cost stickiness, as observed in the negative and significant relationship between $\Delta \log ($ Sales $) * D^{*} V A I C$ and $\Delta \log ($ Cost $)$ shown for the first model of Table 3 (coefficient $=-0.022 ; p$-value $=0.002$ ). These results suggest that on efficiently employing IC, firms tend to sustain current resources when their sales decrease because they may believe IC will enhance future sales and thus the firm will be able to absorb cost incurred on unutilised resources owing to the decline in sales ${ }^{3}$. This

\footnotetext{
${ }^{3} \mathrm{H} 2$ assumes that managers are optimistic about future performance when there is efficient IC because IC could enhance future performance to absorb the costs incurred during periods of sales decline. To confirm that IC could enhance future financial performance, the Pearson correlation analysis is conducted. Based on Chen et al. (2005) and Clarke et al. (2011), three financial performance
} 
optimistic expectation about future performance increases cost stickiness. The result holds on including the control variables in the second model shown in Table 3.

The results for the third, fourth, and fifth models in Table 3 reveal the influence of IC components on the degree of cost stickiness. The results show that HCE and CEE increase the degree of cost stickiness, because $\Delta \log (\operatorname{Cost})$ is significant and negatively related to $\Delta \log ($ Sales $) * D * H C E$ and $\triangle \log ($ Sales $) * D * C E E$ (coefficient $=-0.130 ; p$ value $=0.000 ;$ coefficient $=-0.012 ; p$-value $=0.039$, respectively), but very weakly associated with $\Delta \log ($ Sales $) * D^{*} S C E$ (coefficient $=-0.001 ; p$-value $\left.=0.089\right)$. The results indicate that on average, the firms that employ human, physical and financial capital more efficiently exhibit more sticky costs. Further, human capital increases cost stickiness to a greater extent than physical and financial capital. The possible explanation for this finding is that physical and financial capital would add value to firms more quickly than human capital-for example, firms might use new plant and equipment (capital employed) to produce products in a relatively short period, whereas human capital might not add value to firms equally quickly. For example, new employees may not add value until after gaining experience.

$<$ Insert Table 3 about here $>$

\section{Additional Tests: The effect of IFRS}

On the first of January 2005, Australia adopted the International Financial Reporting Standards (IFRS), as formulated by the International Accounting Standards Board (IASB). While the Australian Accounting Standards Board had been converging the Australian Generally Accepted Accounting Principles (AGAAP) with IFRS, the mandatory adoption of IFRS moved accounting standards towards the introduction of fair value as a preferred basis for measuring assets, while recognizing unrealized gains and losses through changes in the fair value of assets reported in the income statements, along with extensive explanatory disclosures (Australian Institute of Company

measurements are used: ROA, ROE and revenue growth. The time periods are measured by $t+1, t+2$ and $t+3$, where $t$ ranges from 1990 to 2014, as data were only available up to 2017. The results show that VAIC is positively and significantly associated with three future financial performance measurements. Specifically, VAIC is positively and significantly associated with $\mathrm{ROA}_{\mathrm{t}+1}$ (correlation $=0.5523, p$-value $=$ $0.000)$. The table results can be provided upon request. 
Directors (AICD) and Financial Services Institute of Australasia (FINSIA) 2009). The adoption of IFRS in Australia changed accountancy practices for intangible assets, goodwill, financial and taxation instruments, share-based payments and the impairment of non-current assets (see Chalmers et al. 2008, 2011; Haswell and Langfield-Smith 2008). IFRS-led earnings are considered high quality because they represent a series of the best accounting practices in the world, and are more capital-market oriented than many domestic accounting standards owing to the adoption of the fair value measurement basis (Ding et al. 2007). Moreover, IFRS has enhanced the quality of information and the compatibility of financial reporting by promoting a uniform set of accounting standards across the globe (Jeanjean and Stolowy 2008). Consequently, the adoption of IFRS could decrease costs for investors when comparing firms from different markets and nations, helping to boost international investment and integrate capital markets (Covrig et al. 2007).

The literature typically documents conflicting evidence about the effect of IFRS on earnings quality in Australia. Chalmers et al. (2008) examined whether the value relevance of reported intangibles differs between pre-IFRS and post-IFRS periods. They found evidence that IFRS generally conveys incremental useful information to investors about goodwill, while AGAAP provides incremental information to investors in relation to identifiable intangibles. However, Goodwin et al. (2008) and Clarkson et al. (2011) did not find supporting evidence on IFRS adoption leading to enhanced value relevance of accounting information. Lai et al. (2013) examined the change of accruals reliability in the pre- and post-IFRS periods during 1998-2008 for ASX listed firms. They found that accrual reliability declined significantly after mandatory IFRS implementation. Lai et al. (2013) examined the effects of mandatory IFRS adoption on accounting conservatism in Australia. They found that IFRS adoption has led to decreased asymmetric timeliness, but to increased other conservatism measurements. The authors conclude that the question regarding the long-term effects of IFRS on financial reporting conservatism remains unanswered. Jin et al. (2015) investigated the quality of matching between contemporaneous revenues and expenses for the pre-IFRS period (2001-2005) and post-IFRS period (2006-2011). The authors found that the revenueexpense relationship reduced by around $13 \%$ in the former, while the matching between 
revenues and expenses increased in the latter. Their results suggest that IFRS enhanced the quality of matching between revenues and expenses.

This section attempts to add value to the existing conflicting evidence regarding the effect of IFRS on earnings quality in Australia. This section aims to examine how IC efficiency and earnings quality change from pre-IFRS to post-IFRS. Moreover, Bugeja et al. (2015) examined the characteristics and determinants of cost stickiness in Australia using a large sample of Australian listed firms from 1990 to 2010. They found some preliminary evidence that the extent of cost asymmetry increased after the adoption of IFRS. However, they failed to determine how the accounting policy changes caused by the adoption of IFRS would in aggregate affect the degree of cost stickiness. This section extends Bugeja et al.'s (2015) study to examine whether the increased cost asymmetry behaviour in the post-IFRS period was caused by changes in IC efficiency and earnings management constraints.

To provide insights into changes in cost stickiness, this section includes an interaction term between a Post dummy and cost stickiness in the regression analysis, where Post is a dummy variable taking the value of 1 for firm-years after the introduction of IFRS (i.e., from 2006-2016), and 0 otherwise.

Table 4 Panel A presents the descriptive analysis of NOA, IC and its three components before and after IFRS adoption. The results show that IC efficiency increased significantly after the adoption of IFRS: the mean of VAIC (mean $=0.601$ ) before IFRS adoption is lower than that (mean =1.339) after adoption ( $t$-value $=-11.120 ; p$-value $=0.000)$. As regards the three components of IC, $C E E$ increased significantly $(t$-value $=-34.294 ; p$-value $=0.000)$, followed by $H C E(t$-value $=-11.012$; $p$-value $=0.000)$, however, $S C E$ has decreased $(t$-value $=2.011 ; p$-value $=0.022) . N O A$ did not change significantly between the pre-IFRS and post-IFRS periods ( $t$-value $=-0.832 ; p$-value $=0.203$ ).

Table 4 Panel B shows the regression results of the effect of IFRS on the degree of cost stickiness. The first model of Table 4 Panel B shows that the $\Delta \log (\operatorname{Cos} t)$ is significant and negatively related to $\Delta \log ($ Sales $) * D *$ Post $($ coefficient $=-0.013 ; p$ - 
value $=0.039$ ), indicating that cost stickiness is more pronounced in the post-IFRS period. Further, the results presented in Table 4 Panel $B$ show that $\Delta \log ($ Sales $) * D *$ Post $* N O A$ is very weakly significant and positively related to $\Delta \log (\operatorname{Cost})($ coefficient $=0.012 ; p$-value $=0.084)$ in second model. The results of third model in Panel B indicate that on average, IC efficiency increases the degree of cost stickiness more in the post-IFRS period, revealed by the result that the interaction variable $\Delta \log ($ Sales $) * D^{*}$ Post $*$ VAIC is significant and negatively associated with $\Delta \log (\operatorname{Cost})($ coefficient $=-0.015 ; \quad p$-value $=0.000)$. Given the more efficient employment of IC in the post-IFRS period (as shown in Panel A), after the adoption of IFRS, managers are more willing to retain current resources when their sales decrease in the post-IFRS period.

$<$ Insert Table 4 about here $>$

\section{Conclusion}

The literature has examined the determinants of asymmetric cost behaviour (e.g., Anderson et al. 2003; Balakrishnan et al. 2004; Bosch and Blandon 2011; Chen et al. 2012; Bugeja et al. 2015). However, few studies have examined whether accrualsearnings management constraints and IC efficiency affect management asymmetric cost behaviour and whether such behaviour changed after adoption of IFRS in Australia.

This study finds that, when managers have the incentive to avoid unfavourable earnings in the current year but have limited ability to use accruals-earnings management to manipulate earnings, they tend to cut slack resources more aggressively to avoid unfavourable earnings, which leads to anti-sticky cost behaviour. Moreover, the results of this study show that IC efficiency triggers sticky cost behaviour. The reason is that managers may believe that IC would generate future revenue and that the decline in sales is temporary; therefore, they would decide to carry the cost of unutilised resources, aiming to absorb these unutilised resources during periods of increasing demand in the future. Among the three IC efficiencies, HCE increases sticky cost the most, followed by CEE. This study further examined whether asymmetric cost behaviour changed after IFRS adoption in Australia. The results show that such 
behaviour was more pronounced in the post-IFRS period and this increase was because of higher IC efficiency in this period than in the pre-IFRS period.

This study provides important implications for users of financial statements (e.g., investors, financial analysts, auditors, creditors and standard setters) to understand managers' decision-making about cost management. They would understand that under different circumstances, managers' decision on adjusting slack resources owing to decline in demand could vary. Further, users of financial statements could consider the IC efficiency of companies in developing their prediction models to evaluate future firm performance.

This study is subject to several limitations. First, like other empirical research, results may suffer from endogeneity problems. Although this paper used time industry effects models to control for the unobservable confounding variables that differ across time and industry, this study could not fully control for all other unobservable variables that influence explanatory variables. Second, this paper used total operating costs: this measure of costs has been used in many studies (e.g. Chen et al. 2012; Weiss 2010; Via and Perego 2014; Bugeja et al. 2015; Calleja et al. 2006); however, SG\&A cost is the common approach in the cost asymmetry literature. Therefore, findings of this paper should be interpreted cautiously. Third, H2 of this study assumes that managers are optimistic about future performance when firms have efficient IC because they believe that IC could enhance future financial performance. Although this study examines the association between IC efficiency and future financial performance, it fails to find a proxy for CEO optimism. This presents an avenue for future research to determine the proxy of CEO optimism (e.g., CEO overconfidence) and examine the relationship between IC efficiency and CEO optimism to support H2 of this study. Future research could also investigate the influence of other incentives of managers on cost asymmetry, such as management compensation, managerial risk taking. Future study could apply different research methodology to investigate manager motivations and attitudes that affect asymmetrical cost behaviour; for example, experimental methods or interviews. 


\section{References}

Abeysekera, I. 2007, 'Intellectual capital reporting between a developing and developed nation', Journal of Intellectual Capital, 8(2), 329-345.

Abeysekera, I. 2008, Intellectual capital accounting: Practices in a developing country. London: Routledge.

Anderson, M., Banker, R. and Janakiraman, S. 2003, 'Are selling, general, and administrative costs 'sticky'?' Journal of Accounting Research, 41 (1): 47-63.

Anderson, S.W. and Lanen, W.N. 2009, 'Understanding Cost Management: What Can We Learn from the Empirical Evidence on Sticky Costs?', Working Paper, Rice University and University of Michigan. http://dx.doi.org/10.2139/ssrn.975135.

Australian Institute of Company Directors (AICD) and Financial Services Institute of Australasia (FINSIA) 2009, Underlying Profit: Principles of Reporting of NonStatutory Profit Information. Policy Paper, AICD and FINSIA.

Badertscher, B.A. 2011, 'Overvaluation and the choice of alternative earnings management mechanisms', Accounting Review, 86 (5): 1491-518.

Balakrishnan R, Peterson, M. and Soderstrom, N. 2004, 'Does capacity utilization affect the 'stickiness' of cost?', Journal of Accounting, Auditing and Finance, 19 (3): 283-99. Balakrishnan, R., Labro, E. and Soderstrom, N.S. 2014, 'Cost Structure and Sticky Costs', Journal of Management Accounting Research, 26 (2): 91-116.

Banker, R. D., Byzalov, D., Ciftci, M. and Mashruwala, R. 2014, 'The moderating effect of prior sales changes on asymmetric cost behavior' Journal of Management Accounting Research, 26 (2), 221-242.

Banker, R. D., Byzalov, D., Fang, S. and Liang, Y. 2017, 'Cost Management Research', Journal of Management Accounting Research, Forthcoming.

Banker, R.D. and Chen. L. 2006, 'Labor Market Characteristics and Cross-country Differences in Cost Stickiness', Working Paper, Georgia State University. http://dx.doi.org/10.2139/ssrn.921419. 
Banker, R.D., Basu, S., Byzalov, D. and Chen, Y.J. 2016a, 'The confounding effect of cost stickiness on conservatism estimates', Journal of Accounting and Economics, 61 (1): 203-20.

Banker, R. D., Hwang, I., and Oh, H. 2016b, 'Manufacturing capacity utilization and asymmetric cost behavior', Working paper, Temple University.

Banker, R.D., Byzalov, D. and Chen, L. 2013b, 'Employment protection legislation, adjustment costs and cross-country differences in cost behaviour', Journal of Accounting and Economics, 55 (1): 111-27.

Barton, J. and Simko, P. 2002, 'The Balance Sheet as an Earnings Management Constraint', The Accounting Review, 77 (Supplement), 1-27.

Bosch, J.M. and Blandon, J.G. 2011, 'The influence of size on cost behaviour associated with tactical and operational flexibility', Estudios de Economia, 38 (2): 41955.

Bugeja, M., Lu, M. and Shan, Y. 2015, 'Cost stickiness in Australia: Characteristics and Determinants', Australian Accounting Review, 25 (3): 248-61.

Calleja, K., Steliaros, M. and Thomas, D. 2006, 'A note on cost stickiness: some international comparisons', Management Accounting Research, 17 (2): 127-40.

Cannon, J.N. 2011, 'Determinants of 'Sticky Costs': An Analysis of Cost Behaviour using United States Air Transportation Industry Data', AAA 2012 Management Accounting Section (MAS) Meeting Paper. http://dx.doi.org/10.2139/ssrn.1895615.

Chalmers, K., Clinch, G. and Godfrey, J.M. 2008, 'Adoption of International Financial Reporting Standards: impact on the value relevance of intangible assets', Australian Accounting Review, 18 (3): 237-47.

Chalmers, K., Clinch, G. and Godfrey, J.M. 2011, 'Changes in value relevance of accounting information upon IFRS adoption: evidence from Australia', Australian Journal of Management, 36 (2): 151-73.

Chen, C. X., Gores, T. and Nasev, J. 2015, 'Managerial overconfidence and cost behavior', Working paper, University of Illinois at Urbana-Champaign.

Chen, C.X., Lu, H. and Sougiannis, T. 2012, 'The agency problem, corporate governance, and the asymmetrical behaviour of selling, general, and administrative costs', Contemporary Accounting Research, 29 (1): 252-82. 
Chen, M.C., Cheng, S.J. and Hwang, Y. 2005, 'An empirical investigation of the relationship between intellectual capital and firms' market value and financial performance', Journal of Intellectual Capital, 6 (2): 159-76.

Clarke, M., Seng, D. and Whiting, R.H. 2011, 'Intellectual capital and firm performance in Australia', Journal of Intellectual Capital, 12 (4): 505-30.

Clarkson, P., Hanna, J.D., Richardson, G.D. and Thompson, R. 2011, 'The impact of IFRS adoption on the value relevance of book value and earnings', Journal of Contemporary Accounting and Economics, 7 (1): 1-17.

Coulton, J., Taylor, S. and Taylor, S. 2005, 'Is 'benchmark beating' by Australian firms evidence of earnings management?', Accounting and Finance, 45(4), 553-576.

Covrig, V.M., Defond, M.L. and Hung, M. 2007, 'Home bias, foreign mutual fund holdings, and the voluntary adoption of international accounting standards', Journal of Accounting Research, 45 (1): 41-70.

Craswell, A. T., Taylor, S. L. and Saywell, R. A. 1997, 'Ownership structure and corporate performance: Australian evidence', Pacific-Basin Finance Journal, 5(3), 301323.

De Silva, T.A., Stratford, M. and Clark, M. 2014, 'Intellectual capital reporting: a longitudinal study of New Zealand companies', Journal of Intellectual Capital, 15 (1): $157-72$.

Desai, H., Hogan, C. and Wilkins, M. 2006, 'The reputational penalty for aggressive accounting: earnings restatements and management turnover', The Accounting Review, 81 (1): 83-112.

Ding, Y., Hope, O.K., Jeanjean, T. and Stolowy, H. 2007, 'Differences between domestic accounting standards and IAS: measurement, determinants and implications', Journal of Accounting and Public Policy, 26 (1): 1-38.

Doukakis, L.C. 2014, 'The effect of mandatory IFRS adoption on real and accrualbased earnings management activities', Journal of Accounting and Public Policy, 33 (6): 551-72.

Dumay, J. and Tull, J. 2007, 'Intellectual capital disclosure and price sensitive Australian stock exchange announcements', Journal of Intellectual Capital, 8 (2): 23655. 
Goodwin, J., Cooper, B.J. and Johl, S. 2008, 'How Prepared was Australia for International Financial Reporting Standards? The Case of Listed Firms', Australian Accounting Review, 18 (1): 35-45.

Graham, J.R., Harvey, C.R. and Rajgopal, S. 2005, 'The economic implications of corporate financial reporting', Journal of Accounting and Economics, 40 (1-3): 3-73.

Gunny, K. 2010, 'The relation between earnings management using real activities manipulation and future performance: evidence from meeting earnings benchmarks', Contemporary Accounting Research, 27 (3): 855-88.

Guthrie, J. and Petty, R. 2000a, 'Intellectual capital: Australian annual reporting practices', Journal of Intellectual Capital, 1(3), 241-251.

Guthrie, J. and Petty, R. 2000b, Towards the future: knowledge management and the measurement of intangibles. Management Today, 21-23.

Guthrie, J. and Petty, R. 2000c, 'Are companies thinking smart?', Australian CPA, 70 (6): $62-5$.

Guthrie, J., Petty, R. and Ricceri, F. 2006, 'The voluntary reporting of intellectual capital: Comparing evidence from Hong Kong and Australia', Journal of Intellectual Capital, 7(2), 254-271.

Guthrie, J., Petty, R., Ferrier, F. and Wells, R. 1999, 'There is no accounting for intellectual capital in Australia: a review of annual reporting practices and internal measurement of intangibles', Paper presented at the OECD Symposium on Measuring and Reporting of Intellectual Capital, Amsterdam.

Guthrie, J., Ricceri, F. and Dumay, J. 2012, 'Reflections and projections: a decade of intellectual capital accounting research', The British Accounting Review, 44 (2) 68-82. Habib, A. and Hossain, M. 2008, 'Do managers manage earnings to 'just meet or beat' analyst forecasts?: Evidence from Australia', Journal of International Accounting, Auditing and Taxation, 17(2), 79-91.

Haswell, S. and Langfield-Smith, I. 2008, 'Fifty-seven serious defects in 'Australian' IFRS', Australian Accounting Review, 18 (1): 46-62.

He, D., Teruya, J. and Shimizu, T. 2010, 'Sticky selling, general, and administrative cost behaviour and its changes in Japan', Global Journal of Business Research, 4 (1): $1-10$. 
Jeanjean, T. and Stolowy, H. 2008, 'Do accounting standards matter? An exploratory analysis of earnings management before and after IFRS adoption', Journal of Accounting and Public Policy, 27 (6): 480-94.

Jin, K., Shan, Y. and Taylor, S. 2015, 'Matching between revenues and expenses and the adoption of International Financial Reporting Standards', Pacific-Basin Finance Journal, 35 (Part A), 90-107.

Joshi, M., Cahill, D., Sidhu, J. and Kansal, M. 2013, 'Intellectual capital and financial performance: an evaluation of the Australian financial sector', Journal of Intellectual Capital, 14(2), 264-285.

Kama, I. and Weiss, D. 2013, 'Do earnings targets and managerial incentives affect sticky costs?', Journal of Accounting Research, 5 (1): 201-24.

Kim, S. H. and Taylor, D. 2014, 'Intellectual capital vs the book-value of assets', Journal of Intellectual Capital, 15(1), 65-82.

Lai, C., Lu, M. and Shan, Y. 2013, 'Has Australian financial reporting become more conservative over time?', Accounting and Finance, 53(3), 731-761.

Lai, C.Y., Li, Y., Shan, Y. and Taylor, S. 2013, 'Costs of mandatory international financial reporting standards: Evidence of reduced accrual reliability', Australian Journal of Management, 38(3), 491-521.

Lont, D., Wong, N., Cheung, E., Evans, E. and Wright, S. 2010, 'An historical review of quality in financial reporting in Australia', Pacific Accounting Review, 22(2), 147169.

Matolcsy, Z. and Wright, A. 2007, 'Australian CEO Compensation: The Descreiptive Evidence', Australian Accounting Review, 17(3), 47-59.

Murthy, V. and Abeysekera, I. 2007, 'Human capital value creation practices of software and service exporter firms in India' Journal of Human Resource Costing and Accounting, 11 (2): 84-103.

Özkaya, H. and Yükcü, S. 2011, 'Cost behaviour in Turkish firms: are selling, general and administrative costs and total operating costs 'sticky'?', World of Accounting Science, 13 (3): 1-27.

Palmrose, Z., Richardson, V. and Scholz, S. 2004, 'Determinants of market reactions to restatement announcements', Journal of Accounting and Economics, 37 (1): 59-89. 
Phusavat, K., Comepa, N., Sitko-Lutek, A. and Keng-Boon, O. 2011, 'Interrelationships between intellectual capital and performance', Industrial Management and Data Systems, 111 (6): 810-29.

Porporato, M. and Werbin, E. 2010, 'Active Cost Management in Banks: Evidence of Sticky Costs in Argentina, Brazil and Canada', AAA 2011 Management Accounting Section (MAS) Meeting Paper. http://dx.doi.org/10.2139/ssrn.1659228.

Pulic, A. 1998, Measuring the performance of Intellectual potential in knowledge economy. Available at: www.vaicon.net/download/Papers/Measuring the performance of intellectual potential. pdf (accessed June 2009).

Qin, B., Mohan, A. W. and Kuang, Y. F. 2015, 'CEO overconfidence and cost stickiness', Management Control and Accounting, 2015 (2), 26-32.

Subramaniam, C. and Weidenmier, M.L. 2003, 'Additional Evidence on the Sticky Behaviour of Costs', Working Paper, Texas Christian University. http://dx.doi.org/10.2139/ssrn.369941

Tan, H.P., Plowman, D. and Hancock, P. 2008, 'The evolving research on intellectual capital', Journal of Intellectual Capital, 9 (4): 585-608.

Via, N.D. and Perego, P. 2014, 'Sticky cost behaviour: evidence from small and medium sized companies', Accounting and Finance, 54 (3): 753-78.

Weiss, D. 2010, 'Cost behaviour and analysts' earnings forecasts', The Accounting Review, 85 (4): 1441-471.

Wilson, M. and Wang, L. W. 2010, 'Earnings management following chief executive officer changes: the effect of contemporaneous chairperson and chief financial officer appointments', Accounting and Finance, 50(2), 447-480.

Yang, D. C. 2015, 'Growth expectations of management and analysts, and sticky cost behavior', Korean Accounting Information Review, 33 (4), 193-223.

Zang, A. 2012, 'Evidence on the Trade-Off between Real Activities Manipulation and Accrual Based Earning Management', The Accounting Review, 87 (2), 675-703. 


\section{Tables}

Table 1: Descriptive Statistics

\begin{tabular}{lllllll}
\hline Variables & Observations & Mean & Median & Std. Dev. & Min & Max \\
\hline$\Delta \log ($ Cost $)$ & 10048 & 0.105 & 0.077 & 0.416 & -4.656 & 5.507 \\
$\Delta \log ($ Sales $)$ & 10048 & 0.109 & 0.074 & 0.516 & -5.105 & 12.049 \\
D & 10048 & 0.312 & 0.000 & 0.463 & 0.000 & 1.000 \\
SUCC & 10048 & 0.220 & 0.000 & 0.414 & 0.000 & 1.000 \\
GDP & 10048 & 3.093 & 3.500 & 1.188 & -0.400 & 5.000 \\
Asset & 10048 & 19.246 & 19.092 & 2.280 & 12.628 & 25.812 \\
PPE & 10048 & 0.678 & 0.278 & 2.070 & 0.009 & 7.432 \\
EMP & 10048 & 0.159 & 0.111 & 0.653 & 0.024 & 0.873 \\
Avoid & 10048 & 0.308 & 0.000 & 0.190 & 0.000 & 1.000 \\
VAIC & 10048 & 0.868 & 1.880 & 3.348 & -7.576 & 35.597 \\
HCE & 10048 & 0.930 & 0.987 & 1.153 & -6.263 & 34.589 \\
CEE & 10048 & 0.781 & 0.544 & 0.826 & -1.066 & 4.314 \\
SCE & 10048 & -0.843 & 0.007 & 2.539 & -7.698 & 23.675 \\
NOA & 10048 & 1.296 & 0.787 & 1.813 & -0.033 & 17.174 \\
\hline
\end{tabular}

Note: Cost is operating expenses and Sales is operating revenue. Decrease Dummy (D) is coded as 1 when operating revenues in year $\mathrm{t}$ are less than those in year $\mathrm{t}-1$, and zero otherwise. GDP is gross domestic product growth rate. SUCC is revenues declines in the preceding period, which is dummy variable and coded as ' 1 ' if revenue in $\mathrm{t}-1$ is lower than revenue in t-2, 0 otherwise. PPE is Property, plant, and equipment intensity, which is measured by the ratio of property, plant and equipment to sales; Asset intensity (Asset) is measured by the ratio of total assets to sales. EMP is employee intensity, which is measured by the ratio of the employees' salaries to sales. Avoid is managerial incentives to unfavourable earnings, it is a dummy variable that equals 1 if Avoidloss $=1$ or Avoiddec $=1$, and 0 otherwise. Where Avoidloss is dummy variable coded ' 1 ' if firm $\mathrm{j}$ has earnings per share higher than or equal to zero but lower than one cent, and ' 0 ' otherwise. Avoiddec is dummy variable coded ' 1 ' if firm $j$ has earnings per share higher than or equal to that for the previous period but the difference is less than one cent, and ' 0 ' otherwise. NOA is net operating assets, which are measured by shareholders' equity minus cash, and cash equivalent plus total debt divided by lagged sales in t-1. HCE is human capital efficiency. SCE represents structural capital efficiency. CEE is capital employed efficiency. VAIC is the aggregation of HCE, SCE, and CEE. 
Table 2: Regression results for $\mathrm{H1}$

\begin{tabular}{|c|c|c|c|c|c|}
\hline Variables & (1) & (2) & (3) & (4) & (5) \\
\hline & Coef. & Coef. & Coef. & Coef. & Coef. \\
\hline \multirow[t]{2}{*}{ Constant } & 0.038 & 0.044 & 0.009 & 0.003 & 0.010 \\
\hline & $(0.336)$ & $(0.371)$ & $(0.760)$ & $(0.910)$ & $(0.722)$ \\
\hline \multirow[t]{2}{*}{$\Delta \log ($ Sales $)$} & $0.460^{* * *}$ & $0.464^{* * *}$ & $0.747^{* * *}$ & $0.745^{* * *}$ & $0.744^{* * *}$ \\
\hline & $(0.000)$ & $(0.000)$ & $(0.000)$ & $(0.000)$ & $(0.000)$ \\
\hline \multirow[t]{2}{*}{$\Delta \log ($ Sales $) * D$} & $-0.081^{* * *}$ & $-0.073^{* * *}$ & $-0.270^{* * *}$ & $-0.611^{* * *}$ & $-0.625^{* * *}$ \\
\hline & $(0.002)$ & $(0.000)$ & $(0.000)$ & $(0.009)$ & $(0.007)$ \\
\hline \multirow[t]{2}{*}{$\Delta \log ($ Sales $) * D *$ SUCC } & & $0.063^{* *}$ & & $0.282^{* * *}$ & $0.277^{* * *}$ \\
\hline & & $(0.023)$ & & $(0.000)$ & $(0.000)$ \\
\hline \multirow[t]{2}{*}{$\Delta \log ($ Sales $) * \mathrm{D} * \mathrm{GDP}$} & & -0.021 & & $-0.067^{* *}$ & $-0.074^{* *}$ \\
\hline & & $(0.448)$ & & $(0.025)$ & $(0.013)$ \\
\hline \multirow[t]{2}{*}{$\Delta \log ($ Sales $) * D^{*}$ PPE } & & $-0.014^{* *}$ & & $-0.021^{*}$ & $-0.021^{*}$ \\
\hline & & $(0.012)$ & & $(0.077)$ & $(0.071)$ \\
\hline \multirow[t]{2}{*}{$\Delta \log ($ Sales $) * D * E M P$} & & $-0.012^{* * *}$ & & $-0.016^{* * *}$ & $-0.016^{* * *}$ \\
\hline & & $(0.000)$ & & $(0.002)$ & $(0.002)$ \\
\hline \multirow[t]{2}{*}{$\Delta \log ($ Sales $) * D^{*}$ Asset } & & $-0.072^{* * *}$ & & $-0.029^{* *}$ & $-0.029^{* *}$ \\
\hline & & $(0.000)$ & & $(0.012)$ & $(0.013)$ \\
\hline \multirow[t]{2}{*}{$\Delta \log ($ Sales $) * D^{*}$ Avoid } & & $0.122^{* *}$ & & $0.182^{* *}$ & $0.174^{* *}$ \\
\hline & & $(0.017)$ & & $(0.014)$ & $(0.012)$ \\
\hline \multirow[t]{2}{*}{$\mathrm{NOA}$} & & & $-0.006^{* *}$ & $-0.007^{* *}$ & $-0.007^{* *}$ \\
\hline & & & $(0.023)$ & $(0.025)$ & $(0.028)$ \\
\hline \multirow[t]{2}{*}{$\Delta \log ($ Sales $) * \mathrm{NOA}$} & & & $0.242^{* * *}$ & $0.249^{* * *}$ & $0.242^{* * *}$ \\
\hline & & & $(0.000)$ & $(0.000)$ & $(0.000)$ \\
\hline \multirow[t]{2}{*}{$\Delta \log ($ Sales $) * D^{*}$ NOA } & & & $0.011^{* * *}$ & $0.012^{* * *}$ & $0.012^{* * *}$ \\
\hline & & & $(0.005)$ & $(0.004)$ & $(0.004)$ \\
\hline \multirow[t]{2}{*}{$\Delta \log ($ Sales $) * D^{*}$ NOA $^{*}$ Avoid } & & & & & $0.032^{* * *}$ \\
\hline & & & & & $(0.003)$ \\
\hline Year effect & YES & YES & YES & YES & YES \\
\hline Industry effect & YES & YES & YES & YES & YES \\
\hline Number of obs & 10048 & 10048 & 10048 & 10048 & 10048 \\
\hline Adj R-squared & 0.3729 & 0.4244 & 0.5543 & 0.5604 & 0.5614 \\
\hline
\end{tabular}

$p$ statistics in parentheses

${ }^{*} \mathrm{p}<0.10,{ }^{* *} \mathrm{p}<0.05,{ }^{* * *} \mathrm{p}<0.01$

Note: This table presents the results of the determinants of cost stickiness using the following regression model:

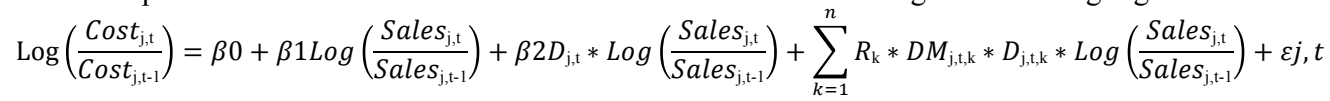

where Cost is operating expenses and Sales is operating revenue. Decrease Dummy (D) is coded as 1 when operating revenues in year $t$ are less than those in year $t-1$, and zero otherwise. GDP is gross domestic product growth rate. SUCC is revenues declines in the preceding period, which is dummy variable and coded as ' 1 ' if revenue in t-1 is lower than revenue in t-2, 0 otherwise. PPE is Property, plant, and equipment intensity, which is measured by the ratio of property, plant and equipment to sales; Asset intensity (Asset) is measured by the ratio of total assets to sales. EMP is employee intensity, which is measured by the ratio of the employees' salaries to sales. Avoid is managerial incentives to unfavourable earnings, it is a dummy variable that equals 1 if Avoidloss $=1$ or Avoiddec $=1$, and 0 otherwise. Where Avoidloss is dummy variable coded ' 1 ' if firm $\mathrm{j}$ has earnings per share higher than or equal to zero but lower than one cent, and ' 0 ' otherwise. Avoiddec is dummy variable coded ' 1 ' if firm $\mathrm{j}$ has earnings per share higher than or equal to that for the previous period but the difference is less than one cent, and ' 0 ' otherwise. NOA is 
net operating assets, which are measured by shareholders' equity minus cash, and cash equivalent plus total debt divided by lagged sales in $\mathrm{t}-1$.

Table 3: Regression results for $\mathbf{H} 2$

\begin{tabular}{|c|c|c|c|c|c|}
\hline Vairables & $(1)$ & $(2)$ & (3) & $(4)$ & (5) \\
\hline & Coef. & Coef. & Coef. & Coef. & Coef. \\
\hline \multirow[t]{2}{*}{ Constant } & 0.040 & 0.071 & 0.066 & 0.053 & 0.045 \\
\hline & $(0.495)$ & $(0.221)$ & $(0.158)$ & $(0.253)$ & $(0.359)$ \\
\hline \multirow[t]{2}{*}{$\Delta \log ($ Sales $)$} & $0.413^{* * *}$ & $0.398^{* * *}$ & $0.464^{* * *}$ & $0.471^{* * *}$ & $0.464^{* * *}$ \\
\hline & $(0.000)$ & $(0.000)$ & $(0.000)$ & $(0.000)$ & $(0.000)$ \\
\hline \multirow[t]{2}{*}{$\Delta \log ($ Sales $) * \mathrm{D}$} & $-0.024^{* *}$ & $-0.034^{* * *}$ & $-0.093^{* * *}$ & $0.093^{* * *}$ & $-0.064^{* * *}$ \\
\hline & $(0.042)$ & $(0.000)$ & $(0.000)$ & $(0.000)$ & $(0.000)$ \\
\hline \multirow[t]{2}{*}{$\Delta \log ($ Sales $) * \mathrm{D} * \mathrm{SUCC}$} & & $0.170^{* * *}$ & $0.139^{* * *}$ & $0.321^{* * *}$ & $0.073^{*}$ \\
\hline & & $(0.002)$ & $(0.001)$ & $(0.000)$ & $(0.077)$ \\
\hline \multirow[t]{2}{*}{$\Delta \log ($ Sales $) * D^{*}$ GDP } & & -0.034 & 0.018 & $-0.119^{* * *}$ & -0.026 \\
\hline & & $(0.377)$ & $(0.528)$ & $(0.000)$ & $(0.367)$ \\
\hline \multirow[t]{2}{*}{$\Delta \log ($ Sales $) * D *$ PPE } & & $-0.009^{* *}$ & $-0.012^{* *}$ & $-0.011^{* * *}$ & $-0.011^{* *}$ \\
\hline & & $(0.011)$ & $(0.014)$ & $(0.000)$ & $(0.013)$ \\
\hline \multirow[t]{2}{*}{$\Delta \log ($ Sales $) * D * E M P$} & & $-0.013^{* * *}$ & $-0.015^{* * *}$ & $-0.007^{* * *}$ & $-0.007^{* * *}$ \\
\hline & & $(0.000)$ & $(0.000)$ & $(0.000)$ & $(0.000)$ \\
\hline \multirow[t]{2}{*}{$\Delta \log ($ Sales $) * D^{*}$ Asset } & & $-0.104^{* * *}$ & $-0.077^{* * *}$ & -0.013 & $-0.074^{* * *}$ \\
\hline & & $(0.000)$ & $(0.000)$ & $(0.180)$ & $(0.000)$ \\
\hline \multirow[t]{2}{*}{$\Delta \log ($ Sales $) * D^{*}$ Avoid } & & $0.066^{*}$ & $0.101^{* *}$ & $0.161^{* * *}$ & $0.019^{*}$ \\
\hline & & $(0.070)$ & $(0.045)$ & $(0.000)$ & $(0.089)$ \\
\hline \multirow[t]{2}{*}{ VAIC } & $0.003^{* * *}$ & $0.005^{* * *}$ & & & \\
\hline & $(0.003)$ & $(0.000)$ & & & \\
\hline \multirow[t]{2}{*}{$\Delta \log (\text { Sales })^{*}$ VAIC } & $0.068^{* * *}$ & $0.069^{* * *}$ & & & \\
\hline & $(0.000)$ & $(0.000)$ & & & \\
\hline \multirow[t]{2}{*}{$\Delta \log ($ Sales $) * \mathrm{D} *$ VAIC } & $-0.022^{* * *}$ & $-0.038^{* * *}$ & & & \\
\hline & $(0.002)$ & $(0.000)$ & & & \\
\hline \multirow[t]{2}{*}{ HCE } & & & $0.116^{* * *}$ & & \\
\hline & & & $(0.000)$ & & \\
\hline \multirow[t]{2}{*}{$\Delta \log ($ Sales $) * H C E$} & & & $0.165^{* * *}$ & & \\
\hline & & & $(0.000)$ & & \\
\hline \multirow[t]{2}{*}{$\Delta \log (\text { Sales })^{*} D^{*} \mathrm{HCE}$} & & & $-0.130^{* * *}$ & & \\
\hline & & & $(0.000)$ & & \\
\hline \multirow[t]{2}{*}{ CEE } & & & & $0.179^{* * *}$ & \\
\hline & & & & $(0.000)$ & \\
\hline \multirow[t]{2}{*}{$\Delta \log ($ Sales $) *$ CEE } & & & & $0.079^{* * *}$ & \\
\hline & & & & $(0.000)$ & \\
\hline \multirow[t]{2}{*}{$\Delta \log ($ Sales $) * D * C E E$} & & & & $-0.012^{* *}$ & \\
\hline & & & & $(0.039)$ & \\
\hline \multirow[t]{2}{*}{ SCE } & & & & & $0.001^{*}$ \\
\hline & & & & & $(0.059)$ \\
\hline
\end{tabular}




\begin{tabular}{|c|c|c|c|c|c|}
\hline Table 3 continued & & & & & \\
\hline Vairables & (1) & (2) & (3) & (4) & (5) \\
\hline \multirow[t]{2}{*}{$\Delta \log ($ Sales $) *$ SCE } & & & & & 0.005 \\
\hline & & & & & $(0.189)$ \\
\hline \multirow[t]{2}{*}{$\Delta \log ($ Sales $) * D^{*}$ SCE } & & & & & $-0.001^{*}$ \\
\hline & & & & & $(0.089)$ \\
\hline Year effect & YES & YES & YES & YES & YES \\
\hline Industry effect & YES & YES & YES & YES & YES \\
\hline Number of obs & 10048 & 10048 & 10048 & 10048 & 10048 \\
\hline Adj R-squared & 0.3438 & 0.3762 & 0.4988 & 0.4804 & 0.425 \\
\hline
\end{tabular}

$p_{*}$ statistics in parentheses

$\mathrm{p}<0.10,{ }^{* *} \mathrm{p}<0.05,{ }^{* * *} \mathrm{p}<0.01$

Note: This table presents the results of the determinants of cost stickiness using the following regression model:

$$
\log \left(\frac{\operatorname{Cost}_{\mathrm{j}, \mathrm{t}}}{\operatorname{Cost}_{\mathrm{j}, \mathrm{t}-1}}\right)=\beta 0+\beta 1 \log \left(\frac{\text { Sales }_{\mathrm{j}, \mathrm{t}}}{\operatorname{Sales}_{\mathrm{j}, \mathrm{t}-1}}\right)+\beta 2 D_{\mathrm{j}, \mathrm{t}} * \log \left(\frac{\text { Sales }_{\mathrm{j}, \mathrm{t}}}{\operatorname{Sales}_{\mathrm{j},-1-1}}\right)+\sum_{k=1}^{n} R_{\mathrm{k}} * \operatorname{DM}_{\mathrm{j}, \mathrm{t}, \mathrm{k}} * D_{\mathrm{j}, \mathrm{t}, \mathrm{k}} * \log \left(\frac{\text { Sales }_{\mathrm{j}, \mathrm{t}}}{\operatorname{Sales}_{\mathrm{j}, \mathrm{t}-1}}\right)+\varepsilon j, t
$$

where Cost is operating expenses and Sales is operating revenue. Decrease Dummy (D) is coded as 1 when operating revenues in year $t$ are less than those in year $t-1$, and zero otherwise. GDP is gross domestic product growth rate. SUCC is revenues declines in the preceding period, which is dummy variable and coded as ' 1 ' ' if revenue in t-1 is lower than revenue in t-2, 0 otherwise. PPE is Property, plant, and equipment intensity, which is measured by the ratio of property, plant and equipment to sales; Asset intensity (Asset) is measured by the ratio of total assets to sales. EMP is employee intensity, which is measured by the ratio of the employees' salaries to sales. Avoid is managerial incentives to unfavourable earnings, it is a dummy variable that equals 1 if Avoidloss $=1$ or Avoiddec $=1$, and 0 otherwise. Where Avoidloss is dummy variable coded ' 1 ' if firm $\mathrm{j}$ has earnings per share higher than or equal to zero but lower than one cent, and ' 0 ' otherwise. Avoiddec is dummy variable coded ' 1 ' if firm $\mathrm{j}$ has earnings per share higher than or equal to that for the previous period but the difference is less than one cent, and ' 0 ' otherwise. HCE is human capital efficiency. SCE represents structural capital efficiency. CEE is capital employed efficiency. VAIC is the aggregation of HCE, SCE, and CEE. 
Table 4: Regression results for additional test (the effect of IFRS)

\begin{tabular}{|c|c|c|c|c|c|}
\hline \multicolumn{6}{|c|}{ Panel A: descriptive statistics of interested variables pre and post IFRS } \\
\hline & $\begin{array}{c}\text { Pre-IFRS (Year } 1990 \\
\text { to 2005) }(\mathrm{N}=4721)\end{array}$ & \multicolumn{2}{|c|}{$\begin{array}{l}\text { Post-IFRS (Year } \\
2006 \text { to } 2016) \\
(\mathrm{N}=5327)\end{array}$} & \multicolumn{2}{|l|}{ T-test } \\
\hline Variable & Std. Dev. & Mean & Std. Dev. & t-value & p-value \\
\hline 1.283 & 1.766 & 1.313 & 1.847 & -0.832 & 0.203 \\
\hline VAIC & 3.358 & 1.339 & 3.277 & $-11.120^{* * *}$ & 0.000 \\
\hline 0.805 & 0.903 & 1.073 & 1.495 & $-11.012^{* * *}$ & 0.000 \\
\hline-0.724 & 2.576 & -0.825 & 2.440 & $2.011^{* *}$ & 0.022 \\
\hline 0.520 & 0.784 & 1.091 & 0.885 & $-34.294^{* * *}$ & 0.000 \\
\hline \multicolumn{6}{|l|}{ Panel B: regression results } \\
\hline \multirow[t]{2}{*}{ Variables } & \multicolumn{2}{|l|}{$(1)$} & (2) & \multicolumn{2}{|l|}{ (3) } \\
\hline & \multicolumn{2}{|l|}{ Coef. } & Coef. & \multicolumn{2}{|l|}{ Coef. } \\
\hline \multirow[t]{2}{*}{ Constant } & \multicolumn{2}{|l|}{0.045} & 0.010 & \multicolumn{2}{|l|}{0.083} \\
\hline & \multicolumn{2}{|l|}{$(0.363)$} & $(0.568)$ & \multicolumn{2}{|l|}{$(0.152)$} \\
\hline \multirow[t]{2}{*}{$\Delta \log ($ Sales $)$} & \multicolumn{2}{|l|}{$0.465^{* * *}$} & $0.551^{* * *}$ & \multicolumn{2}{|l|}{$0.413^{* * *}$} \\
\hline & \multicolumn{2}{|l|}{$(0.000)$} & $(0.000)$ & \multicolumn{2}{|l|}{$(0.000)$} \\
\hline \multirow[t]{2}{*}{$\Delta \log ($ Sales $) * D$} & \multicolumn{2}{|l|}{$-0.048^{* * *}$} & $-0.064^{* * *}$ & \multicolumn{2}{|l|}{$-0.093^{* * *}$} \\
\hline & $(0.000)$ & & $(0.001)$ & $(0.000)$ & \\
\hline$\Delta \log ($ Sales $) * \mathrm{D} * \mathrm{SUCC}$ & $0.068^{*}$ & & $0.297^{* * *}$ & $0.303^{* * *}$ & \\
\hline & $(0.095)$ & & $(0.000)$ & $(0.000)$ & \\
\hline$\Delta \log ($ Sales $) * \mathrm{D} * \mathrm{GDP}$ & -0.041 & & -0.052 & $-0.127^{* * *}$ & \\
\hline & $(0.161)$ & & $(0.102)$ & $(0.002)$ & \\
\hline$\Delta \log ($ Sales $) * \mathrm{D} * \mathrm{PPE}$ & $-0.020^{* * *}$ & & $-0.020^{*}$ & $-0.001^{* * *}$ & \\
\hline & $(0.004)$ & & $(0.094)$ & $(0.001)$ & \\
\hline$\Delta \log ($ Sales $) * D^{*}$ EMP & $-0.002^{* * *}$ & & $-0.016^{* * *}$ & $0.003^{* * *}$ & \\
\hline & $(0.000)$ & & $(0.002)$ & $(0.000)$ & \\
\hline$\Delta \log (\text { Sales })^{*} \mathrm{D}^{*}$ Asset & $-0.069^{* * *}$ & & $-0.036^{* * *}$ & $-0.097^{* * *}$ & \\
\hline & $(0.000)$ & & $(0.004)$ & $(0.000)$ & \\
\hline$\Delta \log ($ Sales $) * \mathrm{D} *$ Avoid & $0.120^{* *}$ & & $0.124^{* *}$ & $0.152^{* *}$ & \\
\hline & $(0.029)$ & & $(0.027)$ & $(0.014)$ & \\
\hline Post & 0.004 & & 0.043 & 0.010 & \\
\hline & $(0.936)$ & & $(0.190)$ & $(0.866)$ & \\
\hline$\Delta \log ($ Sales $) *$ Post & $0.303^{* *}$ & & $0.432^{* * *}$ & $0.373^{* *}$ & \\
\hline & $(0.011)$ & & $(0.000)$ & $(0.034)$ & \\
\hline$\Delta \log ($ Sales $) * \mathrm{D} *$ Post & $-0.013^{* *}$ & & $-0.030^{* * *}$ & $-0.060^{* * *}$ & \\
\hline & $(0.039)$ & & $(0.000)$ & $(0.000)$ & \\
\hline NOA & & & $0.007^{* *}$ & & \\
\hline & & & $(0.023)$ & & \\
\hline$\Delta \log ($ Sales $) *$ NOA & & & $0.174^{* * *}$ & & \\
\hline & & & $(0.003)$ & & \\
\hline$\Delta \log ($ Sales $) * \mathrm{D} * \mathrm{NOA}$ & & & $0.021^{* * *}$ & & \\
\hline & & & $(0.000)$ & & \\
\hline$\Delta \log ($ Sales $) *$ Post*NOA & & & $0.127^{*}$ & & \\
\hline & & & $(0.076)$ & & \\
\hline
\end{tabular}




\begin{tabular}{llll}
\hline Table 4 Panel B continued & & & \\
\hline Variables & $(1)$ & $(2)$ & $(3)$ \\
\hline$\Delta \log ($ Sales)*D*Post*NOA & & $\left(0.012^{*}\right.$ & \\
& & & $0.005^{* * *}$ \\
VAIC & & $(0.000)$ \\
& & $0.157^{* * *}$ \\
$\Delta \log ($ Sales)*VAIC & & $(0.000)$ \\
& & & $-0.067^{* * *}$ \\
$\Delta \log ($ Sales)*D*VAIC & & & $(0.000)$ \\
& & & $0.053^{* *}$ \\
$\Delta \log ($ Sales)*Post*VAIC & & & $(0.032)$ \\
& & & $-0.015^{* * *}$ \\
$\Delta \log ($ Sales)*D*Post*VAIC & & $(0.000)$ \\
& & YES & YES \\
Year effects & YES & YES & YES \\
Industry effects & YES & 10048 & 10048 \\
Number of obs & 10048 & 0.5698 & 0.3902 \\
Adj R-squared & 0.4251 & & \\
\hline
\end{tabular}

$p$ statistics in parentheses

$\mathrm{p}<0.10,{ }^{* *} \mathrm{p}<0.05,{ }^{* * *} \mathrm{p}<0.01$

Note: This table presents the results of the determinants of cost stickiness using the following regression model:

$$
\log \left(\frac{\operatorname{Cost}_{\mathrm{j}, \mathrm{t}}}{\operatorname{Cost}_{\mathrm{j}, \mathrm{t}-1}}\right)=\beta 0+\beta 1 \log \left(\frac{\text { Sales }_{\mathrm{j}, \mathrm{t}}}{\operatorname{Sales}_{\mathrm{j}, \mathrm{t}-1}}\right)+\beta 2 D_{\mathrm{j}, \mathrm{t}} * \log \left(\frac{\text { Sales }_{\mathrm{j}, \mathrm{t}}}{\operatorname{Sales}_{\mathrm{j}, \mathrm{t}-1}}\right)+\sum_{k=1}^{n} R_{\mathrm{k}} * \operatorname{DM}_{\mathrm{j}, \mathrm{t}, \mathrm{k}} * D_{\mathrm{j}, \mathrm{t}, \mathrm{k}} * \log \left(\frac{\text { Sales }_{\mathrm{j}, \mathrm{t}}}{\text { Sales }_{\mathrm{j}, \mathrm{t}-1}}\right)+\varepsilon j, t
$$

where Cost is operating expenses and Sales is operating revenue. Decrease Dummy (D) is coded as 1 when operating revenues in year $t$ are less than those in year $t-1$, and zero otherwise. GDP is gross domestic product growth rate. SUCC is revenues declines in the preceding period, which is dummy variable and coded as ' 1 ' if revenue in t- 1 is lower than revenue in t-2, 0 otherwise. PPE is Property, plant, and equipment intensity, which is measured by the ratio of property, plant and equipment to sales; Asset intensity (Asset) is measured by the ratio of total assets to sales. EMP is employee intensity, which is measured by the ratio of the employees' salaries to sales. Avoid is managerial incentives to unfavourable earnings, it is a dummy variable that equals 1 if Avoidloss $=1$ or Avoiddec $=1$, and 0 otherwise. Where Avoidloss is dummy variable coded ' 1 ' if firm $\mathrm{j}$ has earnings per share higher than or equal to zero but lower than one cent, and ' 0 ' otherwise. Avoiddec is dummy variable coded ' 1 ' if firm $\mathrm{j}$ has earnings per share higher than or equal to that for the previous period but the difference is less than one cent, and ' 0 ' otherwise. NOA is net operating assets, which are measured by shareholders' equity minus cash, and cash equivalent plus total debt divided by lagged sales in t-1. HCE is human capital efficiency. SCE represents structural capital efficiency. CEE is capital employed efficiency. VAIC is the aggregation of HCE, SCE, and CEE. Post is dummy variable that equals 1 if year from 2006-2016, '0' otherwise. 